International Journal of Educational Policy Research and Review Vol.9 (1), pp. 27-40 January, 2022

Available online at https://www.journalissues.org/IJEPRR/

https://doi.org/10.15739/IJEPRR.22.003

Copyright (C) 2022 Author(s) retain the copyright of this article

ISSN 2360-7076

CrossMark

\&click for updates

Original Research Article

\title{
Teaching methods applied in higher education during COVID-19 pandemic in Africa
}

\author{
Received 20 October, 2021 \\ Mahona J. Paschal*1, \\ Titus 0. Pacho \\ and \\ Oluyinka Adewoyin ${ }^{3}$ \\ 1Department of Educational \\ Foundation, St. Augustine \\ University of Tanzania. \\ 2 School of Education and Human \\ Resource Development, Kisii \\ University, Kenya. \\ 3Department of Crop Science and \\ Horticulture, Federal University \\ Oye Ekiti, Nigeria. \\ *Corresponding Author \\ Email: pajo.toronto@gmail.com
}

\section{Revised 15 December, 2021}

Accepted 29 December, 2021

Published 3 January, 2022
The outbreak of COVID has imposed a lot of challenges globally to effective teaching since the first COVID 19 pandemic in Africa. In 2020, different African countries have witnessed a drastic change in economic, social and political sphere of life. In order to avoid further spread of COVID-19 and with strict preventive measures, physical contact teaching was cancelled until further notice. The suspension of physical classes at the universities has brought unique challenges to students and educators in the process of delivering contents of the curriculum and achieving value in the education sector across Africa. Our empirical research aimed at finding out the effective teaching methods adopted by higher educational institutions during COVID-19 Pandemic in Africa. The study employed qualitative study design rooted in a descriptive case study, semi structured interview was used to collect data from ten lecturers from seven countries in Africa. The study found greater satisfaction with teaching and learning methods used in African universities. However, both adaptation and application of new teaching methods in higher learning institutions in Africa are still facing various challenges. Throughout this study, we recommend that each university should invest in technologies and research, consistent internet availability, training and skill acquisition in computer operation.

Keywords: Teaching methods, COVID-19, African universities, higher education, remote education.

\section{INTRODUCTION}

The normal 'Face to face classroom' has been a critical approach for teaching and learning as well as for evaluation among educators and students in higher learning institutions across the world. However, the spread of coronavirus disease COVID-19 around the globe has created a serious tension among policy makers, educators, students as well as educational scholars. The onset of the COVID-19 pandemic has been accompanied by major changes and challenges in many dimensions of human lives (Mahona and Pacho, 2021). Initially, outbreaks began in Wuhan, China, Italy, Iran, and South Korea, and currently are in more than 180 countries across the world. With COVID-19 being a serious threat, the World health Organization decreed that COVID-19 is a global threat (WHO, 2020). When COVID-19 cases were recorded on the African continent in February 2020, many students and teachers adopted E-learning, measures towards the novel coronavirus. However, the rapid increase of the confirmed cases in African countries, the international protocol that were strictly established by the World Health Organization (WHO) to be adhered by all people in each country in order to slow down the spread of the coronavirus ( CDC, 2020), (Miller, 2020). For instance, countries with reported cases in Africa such as Kenya, Nigeria, Rwanda, Madagascar, Uganda and South Africa, adopted approaches to reduce human interactions by imposing several mitigating approaches based on social distancing, lockdown and temporally suspending educational institutions. Some of countries like Tanzania did not implement lockdown strategy (TBC, 2020). These approaches led to cancellation of in-person classes from nursery schools to higher education. The outbreak of COVID-19 pandemic has had a 
profound effect on education sector, forcing educators and students local and international across the world to vacate and wait for further notice from the governments and the universities they were enrolled without even knowing when the universities will be reopened (Batty, 2020), (Sintema, 2020).

\section{General Impact of COVID-19 on education on higher Education in Africa}

The idea that higher education should equip students with skills and knowledge required for solving existing problems has been discussed by many scholars from many disciplines around the world, but the outbreak of coronavirus and its measures such as curfews, quarantine, has negatively affected learning activities globally (Mahona and Pacho, 2021). Like any other country around the globe, countries with reported cases in Africa such as Kenya, Uganda, Tanzania, and South Africa have initiated actions to reduce the few cases of COVID-19 by closing learning institutions (Paschal and Mkulu, 2020). The measures such as social distancing, curfews, quarantine, were enforced to contain the spread of coronavirus led to termination of in-person classes from kindergartens schools to higher learning institutions (Sahu, 2020), (Aina and Opeyeni, (2020), (UNESCO, 2020). Hapompwe et al. (2020) conducted a study in Zambia, their study pointed that indefinite closure of learning institution in Zambia left the students and educators without hope of reopening to proceed with academic matters. The suspension of the in- class delivery of education led to a birth of remote education that was thought to have some merit in the way forward (TAMISEMI, 2020). (Batty, 2020), (Sintema, 2020). (TBC 2020). Coursework adopted strategic modes of remote education which was relatively associated with the application of online in term of teaching and learning (UNESCO 2020a). It argued that conventional approaches to teaching and learning have been with inadequate teaching during the Covid-19. (Batty, 2020), (Sintema, 2020). (TBC 2020). (Paschal and Mkulu, 2020) indicated that during the spread of oronavirus, many educators and students have lost interest in learning and others have been performing poorly as a result of insufficient skills on the application of technology, inadequate funding and facilities in some higher learning in Africa. In line with, Aina and Opeyeni, (2020) portrayed that student staying away from school have affected their performance negatively. These effects have left students and educators with a question of how to facilitate learning. We can note that these effects are the result of the absence of preparation on conducting distance learning in difficult times like the onset of COVID-19 contagious.

\section{The concept of COVID-19 Pandemic}

According to the World health Organisation (WHO (2020), "COVID-19 is a disease caused by a new strain of coronavirus. 'CO' stands for corona, 'VI' for virus, and 'D' for disease. Formerly, this disease was referred to as '2019 novel coronavirus' or '2019-nCoV.' The COVID-19 virus is a new virus linked to the same family of viruses as Severe Acute Respiratory Syndrome (SARS) and some types of common cold. The common symptoms of COVID-19 include shortness of breath, cough and fever (WHO (2020a). WHO further noted that the symptoms are similar to those of common flu and that is why it was crucial for every person with the symptoms to test for the COVID-19. COVID-19 can be transmitted through respiratory droplets of the infected person which is mostly caused by sneezing or coughing (WHO, 2020b) Along with touching the surfaces that the infected person had touched also increases the transmission of COVID-19 (Sun et al., 2020). It is said that the virus can remain on the surface for several hours but a simple disinfectant can kill it. COVID-19 is more likely to affect people with pre-existing conditions of diabetes, heart disease or any other chronic disease (New York Times 2020). Mostly old people are in the key vulnerable risk group. Since this is a new type of virus, scientists are putting many efforts to learn how it can affect the children and the youth age group. As the studies are still conducted, it is still highly recommended for everyone to follow guidelines and safety measures against the COVID-19 virus (WHO 2020c). The world Health Organization (2020) states that there is no treatment yet for COVID-19, and patients diagnosed with this virus are treated based on the symptoms along with enough balanced diet and close assistance from the healthcare providers. However, there are several clinical trials that are being made to discover the treatment or the vaccination against COVID-19 pandemic. To effectuate the need of education during the crisis time, policy makers, educators and scholars raised important concern regarding how quality teaching and learning would be delivered. This concern led to the paradigm shift in teaching and learning delivery resulted to the application of remote education in higher education. In this way, COVID-19 has caused a wide shadow worldwide. The imposition of self-isolation, lockdown and social distancing have never left our education the way it found. Each level of education has faced a new reality leading to some of the most notable ideas to receive little attention in the teaching and learning process. The most notable idea which encouraged students and educators to work in physical group or in the physical teaching and learning environment have received slight attention globally. For example; 'When spider webs unite, they can tie down a lion' Ethiopian Proverbs. It's vital to note that teaching and learning approaches which was used before the onset of COVID-19 have no chance to play during health crisis. Surprisingly, some of useful philosophical ideas have been trending to encourage new means of instructions during COVID-19. The following can be taken as example. Freire (1993) views education as the practice of freedom by which women and men deal critically and creatively with reality and discovers how to participate in the transformation of the world. In line with Freire's view, Dewey (1916) also demonstrated that if we teach today as we taught 
yesterday, we robe our children of tomorrow. Therefore, in this real sense of learning, in order to ensure the teaching and learning processes take place effectively during crisis time, teaching and learning approaches have to be innovated and realistic to solve the existing problem. For instance, one of the most notable quote on the topic of education which encourages and challenging educators and students to be constructive and realistic is from a philosopher and an influential scholar Dewey which states that 'Education is not an affair of telling and being told, but an active and constructive process (Dewey 1916). These central ideas of John Dewey and Freire, have noted the principles that could help not only for educators but also it reminds policy makers to develop a sense of innovation and constructive as a means to address social challenges because their philosophical ideas encourage on learning by practices and reflection of activities to construct meaning. Hence, it must be noted that the secret of bringing attainable change in education during crisis time is to set efforts on inventing new teaching and learning pedagogies rather than applying the old techniques which has lost its value to the $21^{\text {st }}$ century because of lots of changes that have taken place in the society worldwide.

\section{The concept of remote education}

The effect of school closures due to COVID-19 pandemic has worsened how education is practiced. Students in secondary schools and higher education have been separated from their teachers. The teaching and learning processes have been plagued by multiple challenges resulting in remote education and discouragement of physical classroom.

Remote education is also known as distance learning, remote learning, study online, online classes, tele education, (Lwoga, 2014). It refers to the process where an individual can have access to online classes or training using a communication medium without physically being present. This method is gaining momentum due to the abrupt spread of COVID-19 pandemic across different parts of the world. This means that one can easily adjust his/ her timetable to fit within the online classes. Although students may have a different opinion on acceptance of remote education, it is still possible to maintain the blended learning experience with remote learning. (Nagunwa and Lwoga 2012) noted that face to face learning experience can be adapted by webinars and other options in which the facilitator can have access to all the remote learners while still delivering the online learning experience. Also the students have a chance to ask questions and receive promptly answers, chat inbox which overall still functions the same way as the face to face learning ( $\left.0^{\prime} \mathrm{Neil}, 2020\right)$. The key element to remote education is access to reliable internet connectivity (Mtebe, 2018). The learner is more likely to maintain the learning consistency when the internet is sufficient enough to enable them to attend the online classes (Chirwa, 2018). Other factors include conducive infrastructure such as constant electricity supply for the students to charge their laptops and phones. Based on this observation, it should be noted that in order to help the students to be adaptive to the online classes and challenges they might incur, one vital thing educators need to be emphasized is to help their students move online with equity in mind and try to reduce learner anxiety. One can draw an example from Lederman 2020) who stresses that in moving online we recommend that faculty not rely too heavily on synchronous videoconferencing so as not to disadvantage students whose internet infrastructure is poorer, or who use a shared device at home, or who have other family members who need the internet bandwidth for other things" This clearly shows that there are various institutions across Africa that have already held the conversations on remote learning and they are actively involved in making sure that their students experience the best learning experience with minimum stress even during the COVID-19 pandemic. In supporting the concept of distance learning, UNESCO provided a list of different websites, mobile Apps and resources to support parents, schools, school administrations and facilitators to curate the relevant content for the learners to engage during this crucial time (UNESCO, 2020a).

\section{Statement of the problem}

The outbreak of coronavirus (COVID-19) has brought many changes in every dimension of human lives (UNICEF, 2020a). (Coulthard, 2020). (Mahona and Pacho 2021) As much as COVID-19 may look like a health crisis, it has affected various sectors in different fields across the globe (UNDP 2020). In the academic space, schools have closed and hence the learners have been forced to stay home without attending schools. This led the in-person or traditional classroom that was derived using contact teaching and learning approaches to lose its value. The suspension of the in- class delivery of education led to a birth of remote education that was thought to have some merit in the way forward (TAMISEMI 2020). The remote education was practiced in asynchronous and synchronous such as radio, television, Zoom, WhatsApp Email correspondences and YouTube channels (Armstrong, 2020). Coursework and examination adopted strategies modes of remote education which was relatively associated with the application of digital in term of teaching and learning (UNESCO 2020a). However, challenges have always been how to adopt the remote mode of education to make a significant different (Bhalla 2020). (Tagoe, 2012) noted that remote learning was improving in some countries in Africa, but for the whole of the African continent, the remote education faces many challenges because of the insufficient infrastructure facilities such as computers network and some areas have no electricity. In Africa, this may pose an additional challenge as not every student has access to reliable internet and internet facilities. Furthermore, not every university has been able to switch to the online classes, making their respective students stay home idle without continuous learning. 
Independent Variable Intervening variable Dependent variable

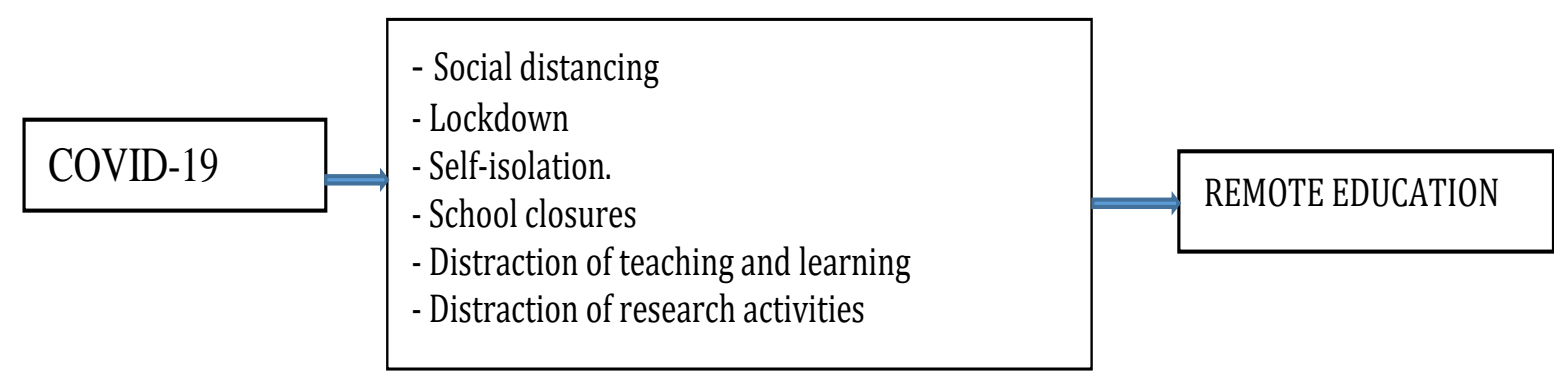

Figure 1: Conceptual Framework

COVID-19 is more than a health crisis, it has affected the education sector as well, and this may take time to recover from the scars of the months lost without learning. Generally, the remote learning in African universities is relatively little known compared to other developed countries like Canada, the Netherlands, the United States of America, and China. As a response to what has been the most serious health crisis of recent times, major transitions have been implemented by higher learning institutions in Africa to overcome the effects of COVID-19 pandemic on education. Therefore, has sought to explore the effective teaching methods employed by higher educational institutions during COVID-19 pandemic in Africa

\section{Study Objectives}

The study aimed at exploring the effective teaching methods adopted by higher educational institutions during COVID-19 Pandemic in Africa.

\section{Research question}

What methods have been adopted in place by universities to enhance effective teaching and learning during COVID$19 ?$

\section{Significance of the study.}

According to UNESCO (2010b), Higher Education has the responsibility to respond to the issue and challenges that affect society and to provide students with skills and knowledge needed to address these challenges'. This study was pursued to support educational stakeholders and policymakers across Africa in becoming informed users of remote education and its significance in educational development and productivity during uncertain time. The study also intended at inspiring students in the utilization of remote education techniques as a vibrant tool to help them thrive during an uncertain time. Also, the study sought to act as a guideline to scholars who may wish to conduct similar study in the nearer future. Generally, this paper provides the shared approaches and experiences in teaching in higher education which are potential to assist students to participate actively in teaching and learning process.

In Figure 1, the Conceptual Framework above shows how the onset of the COVID-19 has brought many changes in various industries including in the education sector which resulted to the emergency of remote education across the globe. This implies that if schools and higher education institutions want to continue offering education during uncertain times, it's advised to adopt remote education.

\section{Related Literature and Studies}

This part of the study presents literature and studies related to methods adopted by higher educational institutions during COVID-19 Pandemic. It involves review of related theory as well as empirical literature of the study.

\section{Constructivist theory}

Our study is underpinned by the constructivist theory which was founded in 1978 by Lev Vygotsky. Generally, constructivist theory states that knowledge is constructed based on a new learning experience of the learner under the help or influence of teachers as facilitators of teaching and learning (Vygotsky, 1978); Ngussa, and Makewa, (2004). From this standpoint, this theory will help educators and students in higher education to develop and adopt a growth mindset that not only will help them thrive despite uncertainty, but will also help them thrive because of uncertainty. Therefore, it is relevant to adopt Constructivist Theory in this study since it encourages individuals to construct innovative approaches and skills in solving various problems.

\section{Teaching and learning methods adopted by higher educational institutions during COVID-19 Pandemic}

The COVID-19 crisis has affected educational practices globally, leading to total closure of universities as well as 
other learning institutions. Most of exams were postponed and irrecoverable. During the closure of face to face learning, teaching and learning has been conducted through the application of computers, tablets, mobile phones and laptops with the internet access (Paschal and Mkulu, 2020; Bozkur et al., 2020; Selvam, 2020; Reimers et al., 2020). Furthermore, Pete and Soko (2020) conducted a survey on the devices that learners and educators use to access internet. The results indicated that, in Ghana, 38 percent used laptop, followed by Kenya 29 percent and 33 percent in South Africa. The study also shows that 21 percent used desktop in Ghana, 38 percent in Kenya, and 17 percent in South Africa. Tablet was use in Ghana at 7 percent, 11 percent in Kenya and 18 percent in South Africa. Regarding the application of mobile phone, Ghana showed 34 percent, Kenya with 23 percent, as well as 32 in South Africa (Pete and Soko, 2020). This signifies that teaching and learning by means of technology can be embraced fully in Africa.

Truly, education during COVID-19 restriction has been greatly supported by the application of technologies worldwide. More specifically, the reviewed work of literature identified several methods as discussed in the following passages;

\section{Use of Learning Management System (LMS)}

Many universities in the world have Learning Management System (LMS) where students and lecturers have their tutorials on these systems. For instance, George, (2020) conducted a study in the republic of Trinidad and Tobago on effective teaching and examination strategies for undergraduate learning during COVID-19. George noted that, My-ELearning teaching platform has been a vital tool for continued support of learners during the face -face learning restriction, even examinations activities have been conducted in this platform. In Algeria, the study conducted by (Redacteur, 2018), noted that the online teaching and learning in Algeria are still underdeveloped regardless of the effort of the country to invest more in the field of education. However, Redacteur, 2018), emphasizes that the majority of public universities in Algeria have already launched digital learning platforms and have registered their students to the Moodle learning systems to help them connect and interact with their lectures (Bozkur, et. al 2020). In Egypt, professors in public universities created instructional audios and videos lectures to share with their students on you tube or the universities' public sites (Bozkur et al., 2020). In Uganda, Kenya, as well as in South Africa, some of the universities' management and faculties advised the lecturers to upload audios, videos and other tutorials to the university Learning Management System (LMS) so that they could help the students to learn and complete their course works (Bozkur et al, 2020; Selvam, 2020; Reimers et al., 2020). Based on the discussion above, it may be concluded that during the suspension of face-to face classroom, the lecturers who used Learning Management System (LMS) such as My ELearning made the learning materials available to be downloaded from the
Learning Management System (LMS) option pages but the lack of electricity and internet connectivity to some of the students has been a big obstacles during their learning specifically in the COVID-19 period and beyond.

\section{Use of Google classroom}

The study conducted in Nigeria by Aina and Opeyemi (2020) noted that Google classroom represents one strategy for mitigating the effects of the coronavirus pandemic. The study conducted by Selvam (2020) in Kenya suggests that Google classroom is one of the apps on google for teaching and learning that helps educators to construct and form assignments easily and provide feedback and communicate with their students from different areas. Dominic et al. (2020) in Ghana and Basher (2017) showed that the application of Google classroom helped educators to spend more time with their learners than with papers. In Egypt, some educators communicated with learners via free Google classroom. Although it has been noted that a few numbers of educators applied Google classroom, it's encouraged that this instructional delivery of learning should be encouraged to be used by the majority of educator in Africa. The google classroom has major parts which are streams, students' activities, and people (Henukh et al., 2020). The streams is applicable for developing learning announcement, to see the flow of created assignments, quizzes and materials prepared from the topic taught (Aina and Opeyemi (2020). The educators use classwork or student's activity to develop test questions, quizzes, and pretests, upload materials and hold reflections of the intended study (Henukh et al., 2020). The use of the people section on the google classroom is used to invite learners using the code available in the bar. Therefore, if there is conducive infrastructure for e-learning in a certain environment, Google classroom can be the best pedagogy that can be adopted during crisis time because it can be accessed anywhere and at any time but the majority of students in rural and urban universities do not access to internet in their home and some students in Africa do not even have laptop, electricity in their home as well as smartphones which could help to access in the online education.

\section{Zoom Classroom}

Gomez et al. (2020) noted that Zoom was used during live classes. Learners used the chat space to ask questions and answer questions asked by fellow students or the course instructor (George, 2020). Private chat between learners with the session instructor or facilitator was available. Zoom has been provided the students and facilitators chances to connect in a Zoom classroom. In Egypt most of the universities such as American University in Cairo employed web enhanced learning such as Zoom and Google Meet which helped students and educators to communicate during teaching and learning process (Bozkur et al., 2020). In Uganda, some of universities such as Uganda Christian 
University and The Makerere University have been applying Zoom and other platforms such as WhatsApp, Telegram and had prepared take-home examination to conclude the Easter semester during the COVID-19 (UCU, 2020); Mulengera News, (2020). Some of the big universities in Uganda such as Makerere University has allowed their students and educators to access to the learning platforms of the universities with no any cost. This helped students and educators to continue with teaching and learning (UCU, 2020; Mulengera New, 2020). In relation to that, Mensah et al. (2020) conducted a study in Ghana, noting that some of the universities in Ghana such as the university of Ghana and Winneba have been facilitating teaching and learning by using Zoom and other platforms. Reimers et al. (2020), as well as Bozkur et al. (2020) also indicate that internationally, learning institutions have switched to e-learning platforms like zoom, Facebook and you tube. However, literature tells that most of the universities in Africa as mentioned in this study have been introducing online learning, the process has been hindered by the lack of electricity as well as unstable internet and elearning platforms. Therefore, it's vital for policy makers and other educational stakeholders to use COVID-19 as a tool to strengthen both international and domestic cooperation in order to enhance mechanism for education development by solving the challenges that facing the delivery of education (UNESCO, 2020)

\section{Email and electronic mailing lists}

Course delivery package such as Blackboard has been critical during teaching and learning after suspension of all physical classrooms during COVID -19 pandemic (Selvam, 2020). Email has been applied for communication among learners and their instructors. Educators have been sending course guidelines, assignments, and quizzes to their students and got the feedback by means of email correspondences. According to George (2020), email consultation involves the course facilitators presenting learners with a tutorial with topics associated with the topic. During Covid-19, students were required to attempt questions in their home, then scan their attempts and send them by email to their course facilitators for assessment and corrections then the lecturers sends the marked assessed work of the students by emailing them back (Bozkur et. al 2020; George, 2020). In Kenya, the closer of universities during COVID-19 led to the immediate shift from physical learning to the digital teaching and learning using digital tools and internet (Selvam, 2020). Although the learning process in some universities has been taking place by means of the internet even before the pandemic, the pandemic accelerated the learning to which continued based on sending learning materials, assignment to students via emails and other methods such as Google classrooms which (Selvam, 2020); (Baran et al., 2013). However, most students and educators could not apply these methods because most of them are not familiar with the digital tools such as computers even the internet itself has been expensive as well as too slow (Bozkur, et al, 2020). Hence, most of the students and educators did not prefer this method of learning system as they could not get access to the digital learning because they could not afford learning tools such as smartphones and computers because of their economic status and social situations. It must be noted that most of students have been complaining because of the inadequate instruction help from their lectures who have been sending the learning materials as well as assignment by means of emails.

\section{Supplementary sheet and other self-home study materials}

Students were given supplementary worksheets at the beginning of the semester, however the application of these worksheet begun after the suspension of the physical classroom (George, 2020). In Uganda, some of the universities and schools have been distributing Supplementary sheet and other self-home study materials to students (Bozkur et al., 2020). These materials have been provided in printed format and some live presentations in SD or DVD (Bozkur et al., 2020); (Hapompwe et al., 2020). This implies that students could accomplish the supplementary sheet for each subject required by their course facilitator by emailing the sheets.

\section{Social Media: Facebook, YouTube, WhatsApp, Telegram}

Soon after the onset of COVID-19 Pandemic and its learning restrictions, the majority of lecturers moved teaching online and attempted to use the social Medias strategies to deriver learning materials for their courses to their students (George, 2020). Some invested time to develop online videos and uploaded them to be used by their students (NBS News (2020). In Egypt, Kenya, Uganda, Algeria as well as in South Africa, professors in public universities created instructional audios and videos lectures to share with their students on You Tube or the universities public sites (Bozkur et al., 2020); (Reimers et al., 2020). Others have been learning by using Social Media such as Facebook, YouTube, WhatsApp, Telegram (Selvam, 2020). Like so many African learning institutions, the success of learning online using these social media depends on digital skills and good internet connectivity in the learning environment. Some of these social media tools are WhatsApp.com, Skype.com, Telegram.com and Youtube.com, The application of these tools in education influence online learning and they help in accessibilities of teaching and learning materials through the internet (Paschal and Mkulu, 2020). In Zambia, Facebook, YouTube, WhatsApp, Telegram have been encouraged to be used by the lecturers and students so that the learning could have a broader range of learning methods (Hapompwe et al., 2020). It must be noted that, these social media platforms such Facebook, YouTube, WhatsApp and telegram can provide instant and fact interaction among students and learners but the challenge is that they need skills and 
Table 1. Number of lectures sampled from each country

\begin{tabular}{lcc}
\hline Country & Frequency & Percentage \\
\hline Kenya & 1 & $10 \%$ \\
Nigeria & 2 & $20 \%$ \\
Rwanda & 1 & $10 \%$ \\
Uganda & 2 & $20 \%$ \\
Namibia & 1 & $10 \%$ \\
South Africa & 2 & $20 \%$ \\
Tanzania & 1 & $10 \%$ \\
Total & $\mathbf{1 0}$ & $\mathbf{1 0 0 \%}$ \\
\hline
\end{tabular}

Source: Researchers' construct (2021)

training as well as electricity in operating them. Therefore, it is vital for every country in Africa to provide support to universities and other learning institutions so that they can invest much in teaching and learning including improving the teaching pedagogies.

\section{METHODOLOGIES}

\section{Research Design}

The study employed qualitative study design rooted in a descriptive case study. This design takes into consideration the perception of a phenomenon as stated by Coe 2020). It aim at describing, representing and providing a clear understanding and view of the educational world. In this case, the purpose of the study was to understand the effective teaching and methods adopted by higher educational institutions during COVID-19 Pandemic in Africa.

\section{Population, Sample and sampling techniques}

The targeted population of this study involved all the lectures in African universities. Annum, (2017) stated that an accessible population is where researchers draw their samples. The accessible population of this study contained lecturers in seven selected countries in Africa. Lopez and Whitehead, (2015) recommend that a range of respondents from eight to fifteen respondents are useful to provide information to researchers. This recommendation are basis on the claim that samples in the qualitative study are small and based on providing the data needed for the study (Polit and Beck, 2010). Hence, this has informed the choice of researchers to choose purposively 10 lecturers for this study from seven universities in Africa. Agyedu et al. (2013) noted that purposive sampling helps researchers to get access in depth information of a selected population. Table 1 shows the number off lectures sampled from each country.

\section{Research Instrument}

The study instrument used in this study was semi structured interview. Annum, (2017) indicated that an interview is an interaction between one person and on other or people in a group where oral questions are being asked by the researcher or an interviewer. Annum (2017) opines that interviews help researchers to meet with the interviewee in a face to face method and generate ideas in a conversation way. To recruit the respondents for this study, the researchers sent a message to the journal club WhatsApp group which comprised researchers, students and lecturers from different universities in Africa calling for their interests to the study. The interview was held using the zoom platform.

\section{Trustworthiness and confidentialities}

The trustworthiness of this research was ensured by including respondents offering viewpoints and credibility to the findings. Confidentiality was enhanced by not sharing respondents' personal information with other respondents or an individual.

\section{Data collection and analysis}

The researchers used one hour with participants to solicit for their view on the effective teaching methods adopted by higher educational institutions during COVID-19 Pandemic in Africa. The interview information were analysed using qualitative content analysis.

\section{Ethical considerations}

All participants of this study were given an assurance of confidentiality and anonymity in reporting their information as well as seeking their consent.

\section{Limitations of the study}

A major limitation of this research is that it emphases only on lecturers and leaves out other education stakeholders such as the students themselves, policymakers and administrators Another limitation is that the study is an general idea of the universities in the whole continent of Africa rather than an in depth analysis of universities in a specific country. This means that the synthesised data may 
not be relevant in other areas.

\section{FINDINGS AND DISCUSSION}

Specific Objective aimed at exploring the effective teaching methods adopted by higher educational institutions during COVID-19 Pandemic in Africa. Under this objective some questions were asked to respondents, they were as follows; do you apply online teaching and learning methods at your university? If yes, how was the university arrived at the decision to teach online? If NO, why? What methods have been adopted in place by universities to enhance effective teaching and learning during COVID-19? What possible Strategies that should be implemented by universities to improve teaching and learning in Africa during COVIDpandemic?

Do you apply online teaching and learning methods at your university? If yes how did the university arrived at the decision to teach online?

In this question, the researcher wanted to find out whether lectures have been applying online methods in teaching during the pandemic. The responses were as follows:

Six respondents, 4 male and 2 female lecturers said YES they have been using online teaching during COVID-19 pandemic. During interview one participant from those said YES and those who said NO was chosen purposively to represent the respondents. One among respondents who accepted that they use online teaching said;

'I am using online methods in delivering knowledge to my class for one reason just because it is a requirement resulted from the imposition of self-isolation, lockdown and social distancing, and so we are supposed to do it. The introduction of e learning at our university was followed by the training given by two lectures from America who trained us how to administer online education. But if you ask me, if I am a supporter of online education in my university, I am very sceptical, as I think only few individuals do it."

One among the four respondents who said 'NO' noted that:

'The university did not implement online classes during pandemic because of the decision from the top-down. An order from the ministry of higher education. We lecturers had very little say, if any at all. I can also say that the introduction of online education in our premises and in some universities has been hindered by the lack of trained staff members who could train other lecturers in using elearning. We have no stable electricity, internet connectivity in our university as well as in most of places where our students are living. Online education has very big challenges, big time challenges, because this is a new thing as I have said, our students and my fellow lecturers unfortunately don't take it as a learning experience, they see it as torture. When you give a person task for instance to present online, they don't take it as a challenge to challenge themselves that I want to do better, I want to become better, if you have that positive outlook, it will be a learning experience, but if you don't have that positive outlook then it becomes a horrific task. That's how the pandemic has affected our teaching and learning and maybe is because of poor technology in African and inadequate training.'

\section{What methods have been adopted in place by universities to enhance effective teaching and learning during COVID-19?}

This research question had the primary aim of finding out, the methods have been adopted in place by universities to enhance effective teaching and learning during COVID-19 in Africa.

The study found various methods have been applied by the lecturers in different universities in Africa. During interview, the participants from six countries mentioned in this study mentioned teaching and learning methods such as Facebook, YouTube, WhatsApp and other learning platform like Telegram Learning Management System, zoom, Google classrooms have been implemented to enhance teaching and learning during the COVID-19 pandemic in Africa. However, the result of the study indicated that the onset of COVID-19 pandemic has worsened the whole process of education, and has made learning and teaching to be boring and uninteresting because not all the students have laptops, smartphones or electronic gadgets to enhance online learning by using method like Social Media such as Facebook, YouTube, WhatsApp and other learning platform like Telegram Learning Management System, Zoom, Google classrooms to access the internet, as well as needed information (Bozkur et al., 2020). Paschal and Mkulu (2020) underscored that most students and educators could not apply digital teaching and learning methods effectively because most of them are not familiar with digital tools such as computers even the internet itself has been expensive as well as too slow. Lecturers also have not been unhappy with the imposition of e-learning in their universities because it costs energy, money and time from training to the implementation. Many lecturers have been facing challenges in developing teaching materials as well as uploading the materials to the learning platforms has been a big issue to most of lecturers in African universities due to the lack of training, poor network connectivity, expensive data bundles, lack of computers and computer facilities. It was established that governments should support universities, faculties by helping the country to solve the issues related with electricity, internet connectivity which will allow students to study where they are without any challenge.

During the interview, the respondents who implemented online classes mentioned and expressed their view on various methods which have been adopted in place by universities to enhance effective teaching and learning during COVID-19 in Africa as following. The respondent's responses including; 
'My English department at the university conducted online classes during social distancing and lockdown by handling Zoom. At first, senior lecturers were provided assistants by the university. Zoom has been great temporary fix and we did pretty well during the pandemic. However, we did not perform as it's needed during digital classes because we had a lot of absenteeism. We African know that teaching and learning work best with full physical presence of everyone involved in the classroom. So given a choice, I would definitely vote for face to face learning, maybe blended if necessary.' (Lecturer 1)

Another respondent articulated:

'I teach online research mentorship for university students in Kenya and abroad. We used Zoom classroom, WhatsApp and telegram even before the pandemic to help students who are learning from far. We have been connected with over 20 universities from Africa and some from other continents. The initiative was for university students to learn about research, the platform was called Journal club .so we have both local group and international which was basically from United Kingdom and Canada. However, the big challenge is that, most of Students do not have proper devices to help them use online learning and this has been a big challenge. Also the few students who have devices such as laptops and smartphone are online most time and do multi tasks, so they are not motivated to learn because they have to keep waiting in the zoom rooms so they feel bored and send nut stuffs and log out ,it becomes an issue.' (Lecturer 2)

Another respondent noted:

'Like many other learning institutions in Africa, our university started using Learning Management System, Microsoft team which was easy because we have already used that before the pandemic., it was easy for our students as they used on their own studies as well as with a supervisor. At first in 2020 our students were confused on how to do that, they used WhatsApp before but then to Microsoft team. Students have their own account so it was easy to learn, do assignment and send back, the challenge was when lecturers salary were reduced so it was another challenge then they try to switch to Kaizala because it sends pictures more quickly compare to Microsoft team, Learning Management System which has a lot of challenges on internet .In this platform you can see people like face book so they dropped to use that because it happens one of the student were having a friendship with an old guy from the platform for security reason they decided to stay using Microsoft team .We have been having training on how to handle students who are slower on how to deal with them, how to share the screen. Generally, the online was a worst because students use computer from morning and students are getting tired, the students feel the gap compared to face to face learning. The integrate is breaking as supervisors help students when working at home. The students are not provided with feedback all at once, and during face to face they do that. Lecturers also break down the curriculum because they are not straight forward. Assessment is not well conducted during online, because students is working alone compare to face to face.' (Lecturer 3)

Another respondent had this to say:

'I teach English as a foreign language at the university was trained to use zoom with google class which were used later, there was online courses conducted before the use of other online platform such as Facebook, WhatsApp, and google classroom. The challenges you can agree with time but other stuffs interfere and change the time planned, so it was difficult for students to access materials or time management and sometimes students do not have gadgets. Also you cannot teach topics as planned when using online classes compare to traditional ways, so you have to change objectives and expectations. The engagement is better during one and one the assessment grading is challenging, also when they type will be corrected but when typing online they will be guided with computer, so it is not easy to assess when they do online.' (Lecturer 4)

Another respondent explained:

'My colleague and I are having a program called Tech vantage even before pandemic which aim to support students who are coming from vulnerable environment to learn basic skills of computer to help students use technology in learning, also expose them to opportunities ahead of them. During pandemic, I advised the administration to try online classes which was easy. So the classes was conducted through real time chat, and presentation in WhatsApp platform, it was a bit difficult at the beginning as students didn't know how to send and open the download documents so ,a simple orientation was given to help them on that. The students use rubric for assessment so it is easy to use even when students work individually, because we share our expectations .Last but not least, using virtual classes is easier if we try to use link , games and platform which are friendly in teaching and learning.' (Lecture 5)

A respondent spelt out:

'Online teaching and learning was a good idea because it helped the teaching and learning process to take place despite the COVID-19 Pandemic. We started with WhatsApp, telegram, emails group which involved both lecturers and students, We used to send assignments to students and recorded voice note during teaching or instructing the students ,then we moved to zoom platform. We had one month using it but was very challenging for lower students ,so they later tried Microsoft team because it was friendly ,it was simple to transform from the previous platform to the zoom .The staff members agreed in the meeting to use Microsoft team from zoom ,so we decided on that and start implementing. We had training on ICT on how to conduct classes control students during online classes. However, online classes were very challenging because of the internet break most time. Online teaching was a bit challenging. There is no honest on the issue of integrity, but it help us so we can think on how we can make it better to use in Africa'. (Lecturer 6).

Despite the fact that some of the universities have been implementing online teaching and learning, some universities did not even try to use online education. In this 
study some of respondents implemented the following methods in teaching and learning during the COVID-19 pandemic.

\section{Dividing the class into small units and staggering class contact hours.}

In bridging the gap of education some of the universities in Africa used Dividing the class into small units and staggering class contact hours' method. During the interview, the following respondents had the following to say under these methods of teaching and learning:

'I like that you think to research about these things. Teaching and learning in our country was pretty the same because we have certain benchmarks to set our sights upon. Most of students in the universities including ours have been continuing learning. We have been dividing the class into small units and staggering class contact hours. However, the added pressure of time was felt big but this methods was such a good idea to our university because students couldn't stay home idle due to the pandemic.' (Lecturer 7).

In line to the respondents above, another respondent noted that:

'I can say dividing the students to be smaller in number to attend lectures in a big room has helped our faculty to thrive in the crisis time. We allowed 15 students out of 60 to attend one lecture per day because we have been trying to maintain social distancing. The effect of dividing a large number of students which was included before the pandemic came to be a big challenge because in the crisis we have been teaching just a few students which costed us to teach a few parts of the curriculum per week compared to the time before the pandemic when we taught our students in one open classroom.' (Lecturer 8)

\section{Distribution of Printed books, home package, Supplementary sheets and other self-home study materials}

This is another method of teaching and learning which has been implemented by the universities in Africa. This method seems to be traditional in nature but it has helped students and lecturers to thrive during the COVIDPandemic. Under this method, the respondents had the following to say.

'When learning institutions shut down in Uganda, most of the school turned to online education. However, we majority of the learning institutions raging from primary to university level of education printed the learning material such books and other handouts which have been distributed to the students to be used at home during the crisis time. For instance, after handling the books and topic guideline to the students, I was able to call my students in a normal call or phone chat with them by SMS to inform which topic they should cover and when. These methods helped us so much but I won't end my time without telling you that although it seems the best method for us and our students to continue learning, producing books and learning materials was a challenge because we have many students in our university. Some did not even come back or provide their mailing address for the university to send them.' (Lecturer 8)

Another respondent had the following concern:

"I just cannot imagine because I have not implemented that kind of study. However, in Tanzania we have not been in lockdown, we also did not teach online especially at SAUT. The only way we used to continue with teaching and learning was to maintain social distancing in a face to face classroom. We also gave course guidelines and some study materials like books to the class representative who printed and distributed to the students. Office visitation was made by appointment while both lecturer and the students have been wearing masks and usage of hand sanitizer to avoid the contamination of the virus.' (Lecturer 9)

\section{Task-based method}

Another method for teaching and learning implemented during COVID-19 pandemic in African universities was task-based method. During the interview one of the respondents described that;

'After the stay -home announcement was stated by the country, I quickly realized that our education was about to change. I used the course guideline to develop some questions as assignment to be done at home during the home stay time. I also gave some of the books to be read in a handout as well as I gave a task to write some note. Up today, I Moderate the scope of the lesson plan by focusing on the aim and contents of the study. I do not include too much information in my PowerPoint slides so that I print for my students only the needed information, yet in a simple language which is easier for them to understand while studying at their home.' (Lecturer 10)

What Strategies that should be implemented by universities to improve teaching and learning in Africa during COVID-pandemic?

In this section, the question aimed at exploring the possible strategies that can be used to improve teaching and learning in higher education, especially during the pandemic and beyond. As it has been observed, some of the challenges facing the application of teaching and learning methods during the crisis, these strategies from the interviewed lecturers can improve education if applied.

One of the respondents pointed that:

'Universities should support and utilize blended approach, this proves more engaging and interactive with impact on students' engagement on all levels also other education stakeholders such as ministry of education and the ministry for higher education need to think of the ideas of incorporating digital skills in teaching and learning from a grassroots level so as to help learners get used of it from the very beginning.' (Lecturer 1) 
Another respondent explained:

'The universities managements need to improve network connections. Also to introduce strict regulations to limit the time spent by lecturers and students on the internet for the sake of the study process. The government also should provide extra healthcare and tips to education professionals who have to teach online. I believe what suffered the most during our transitions to online learning was our state of health.' (Lecturer 2)

Also a respondent number 3 indicated that:

'Reduction of charges by netbook provider, also the governments in Africa should provide assistance in obtaining good connectable internet devices as well as a strong sensitization and training of the use, pros and cons of these devices.' (Lecturer 3)

Another participant described that:

'Universities have to accept that it is not physical, so lecturers need to think of others if they want to engage students, so they need to be flexible and adjusting accordingly. Also they need to use methods that can be accessible to students and friendlier. It is difficult but somehow sort of learning.' '(Lecturer 4)

In order to have a productive and quality education a respondent spelt out that:

'Provide enough network facilities to the tutors and the learners' service providers. The university management should provide more digital accessories to be offered to the learners and tutors.' (Lecturer 5)

Another lecturer noted that:

'The managements in African learning institutions should organize training such as seminars and workshop to help lecturers learn as much as possible on the use of online tools and approaches that are applicable in teaching and learning so that to make better education in Africa.' (Lecturer 6)

Also a respondent indicated that:

'Lectures involving large number of learners should be divided into small units and staggering class contact hours. 'I can say dividing the students to be smaller in number to attend lectures in a big room can help students and faculty to thrive in the crisis time. This will also help students to learn better in a healthy environment.' (Lecturer 7)

Participant indicated that:

'The universities in Africa should make sure they send the learning materials such as books and handout as well as guideline to students regularly. This will help the students understand that they are cared for, and can feel they are important part of the learning process.' (Lecturer 9)

Another respondent noted that:

'Lecturers and the head of each department should distribute the tutorials slides and other important information to help the learning process.' (Lecturer 10)

The findings of this study imply that online teaching is what majority of lecturers are using in spite of its challenges. If the education stakeholders such as administrators in universities governments provide training and improve internet facilities, divide the lecturers in a small number of students, provide learning materials will help in bringing effective teaching and learning among higher learning institutions in Africa. In line to that improving ICT facilities will help lecturers to provide needed information and materials to students.

\section{Conclusion}

The 'Face to face classroom' has been a critical approach for teaching and learning as well as for evaluation among educators and students in higher learning institutions across the African countries. However, the spread of coronavirus disease COVID-19 around the globe has created a serious tension among policy makers, educators, parents, students as well as educational scholars. The pandemic has been accompanied by major changes and challenges in many dimensions of human lives. Among the changes has been the abrupt shift to online teaching and learning resulted by the onset of COVID-19 pandemic which has created a serious interruption for the learning institutions especially managing staffs, administrators, lecturers as well as students. This disruption has extended not only in the economic system of the people but also academic sector. The teaching and learning has been greatly affected and the universities have adapted elearning in order to continue with teaching and learning during the social distancing and lockdown. Various methods were adopted which include zoom, google classroom as well as social media such as WhatsApp, telegram, distribution of printed books and other home study materials. However, the use of these methods have encountered a number of challenges including poor network connectivity, inadequate training as well as lack of stable devices to make the success of distance learning. In this study we encourage the universities managements in Africa to improve internet connection in the universities area so that learning will be in smooth way. We also encourage the lecturers to divide the students to be smaller in number to attend lectures in a big room something that can help students and faculty to thrive in the crisis time. Last but not least, the application of blended methods is crucial to be adapted in the crisis time. Hence universities should apply both online as well as offline pedagogies because they complement to each other.

\section{Recommendations}

The study puts forth the following recommendations in order to achieve enhanced teaching and learning conditions during the crisis time:

- Universities in Africa should improve internet connection in the university areas to enable effective learning and teaching

- lecturers should group the students in smaller numbers to attend lectures in a big room.

- Application of blended methods (WhatsApp, telegram, google classroom, google meet) is crucial to be adapted in the crisis time. 
- Universities should apply both online as well as offline pedagogies because they complement to each other

- $\quad$ Parents to provide individual laptop and data for students

- The university management should organise training of lecturers and students in the use of online teaching facilities

- Improvement in the ICT centre of university with competent personnel to address issues promptly from students and lecturers

- Infrastructural improvement of the ICT facilities within the university institution in Africa.

\section{Conflict of interests}

The authors declare that there is no conflict of interests regarding the publication of this manuscript.

\section{REFERENCES}

Agyedu GO, Donkor FA, Obeng S (2013). Teach yourself research methods. Kumasi Campus University of Education Winneba.

Aina JK Opeyemi AA (2020). Mitigating the impact of COVID-19 on the teaching and learning Science in the Nigerian Higher Education. Int. J. Res. and Innovation in Soc. Sci. (IJRISS) Volume 4 issue 6

Amstrong O, Oduor C, Lugano G, Hawi R (2020). Kenya Survey Report, Corona Virus Threat, Country Response, Village awareness and Preparedness. https://www.nation.co.ke/oped/opinion/Covid-19-testsself-learning-skills-of-students-today/440808-5534756134a8bhz/index.html.

Annum G (2017). Research instruments for data collection. Retrieved in July $21 \quad 2016$ from https://campus.eucadium.com/newmdiart/file.../ugraRe search/...Approaches. ( $3^{\text {rd }}$. ed) Thousand Oaks California: Sage.

Baran E, Correia APA, Thompson A (2013). Tracing successful online teaching in higher education: Voice of exemplary online teachers. Teachers College Record, 115(3):1-41.

Basher SAO (2017). The impact of google classroom application on the teaching efficiency of pre-teachers. Retrieved https://www.reserchgate.nrt/publication/

Batty D (2020). Cambridge Colleges criticised for asking students to leave over coronavirus. The Guardian. https://www.theguardian.com/education/2020/mar/18 /cambridge-colleges-criticised-for-asking-students-toleave-over-coronavirus.

Bhalla D (2020). Digital empowerment- A Need for Strengthening Teachers' Role. International J. Engineering Research and Technology (IJERT) 9(6): 840851.

Bozkur A, Jung L, Xiao J, Vladimirschi V, Schuwer R, Egorow G, Larmbert S, AL-fresih M, (2020) A global outlook to the interruption of education due to COVID-19 pandemic: Navigating in a time of uncertainty and crisis. Asian J. Distance Education 15(1):1-126.

CDC (2020). Corona virus Disease 2019(COVID-19). Steps to prevent Illness.

https://www.cdc.gov/coronavirus/2019-nov/index.html

Chirwa M (2018) Assess the use of internet in technology and learning at two selected teachers college in Tanzania. International journal of education and development using Information and Communication Technology (IJEDICT, 14(1):4-21.

Coe WL (2012). Social research methods: Qualitative and quantitative approaches. Boston: Allyn \& Bacon.

Coulthard P (2020). Dentistry and coronavirus (COVID-19) - MORAL decision-making. British Dental Journal. 228(7):503-505.

Dewey J (1916) Democracy and Education. New York: Maximillian

Dewey J (1916/2001). Democratic and Education. Simon \&Brown

Freire P (1993). Pedagogy of the oppressed. Penguin Books.

George ML (2020). Effective and Examination strategies for undergraduate learning during COVID-19 school restrictions. Journal of Education Technology System $0(0)$ $1-26$

Gomez E, Azad J, Magid D (2020). Innovation born in isolation: Rapid transformation of an in-person medical student radiology elective to a remote learning experience during the COVID-19 Pandemic. Academic Radiology.

Hapompwe CC, Kukano C, Siwale J (2020). Impact of Covid19 on Zambia's 2020 General education Examination Candidate' Academic Performance in Lusaka: E-Learning Issues. Int. J. Sci. Res. Publications. 10(5):647-654.

Henuikh A, Rosdianto H, Oikawa S (2020). Implementation of google classroom as multimedia learning. J. Physics Education, 5(1):38-44

Lederman D (2020). The shift to remote learning: The human element. https://www.insidehighered.com/digitallearning/article/2020/03/25/how-shift-remotelearning-might-affect-students-instructors-and.

Lopez V, Whitehead D (2013). Sampling data and data collection in qualitative research. In. Nursing \& Midwifery Research: Methods and Appraisal for evidenced base practice. $4^{\text {th }}$ edn.

Lwoga ET (2014). Critical success factors for adoption of Web based learning Management system in Tanzania. International journal of education and development using Information and Communication Technol.,10(2):4-16

Mahona, P, Pacho T (2021). Reshaping education in the post- COVID-19 pandemic in Africa. Afri. Res. J. Educ. Soc. Sci. 8(3):13-26

Mensah DKD, Mphil EO, Adu-Boahen K, Amankwah LO (2020) Assessment of strategies for teaching and learning during COVID-19 pandemic in a Ghanaians university : Realities and Challenges. Educ. Res. J. 10(9):277-285. Miller ED (2020). The COVID-19 Pandemic Crisis: The loss 
and Trauma Event of our Time. J. Loss and Trauma 1-13. Mtebe JS, Raphael C (2018). A Critical review of E-learning Research Trends in Tanzania. J. Learning Development, 5(2)163-178.

Mulengera News, (2020, May 6) MTN Uganda offers

Makerere Students, Lecturers free access to Online Study platforms. https://mulengeranews.com/mtn-ugandaoffers-makerere-students-lecturers-free-access-toonline-study-platforms/.

Nagunwa T, Lwoga ET (2012). Developing E-Learning Technologies to implement Competence Based Medical Education: Experience from Muhimbili University of Health and applied Science. International journal of education and development using Information and Communication Technol. 8(3):7-21

NBS News (2020). Students at 25 colleges sue for refunds after campuses close because of coronavirus. https://www.yahoo.com/news/students-25-universitiessuerefunds-200447664.html.

New York Times, (2020).The workers who face the greatest coronavirus risk. New York. Available:https://www.nytimes.com/interactive/2020/0 3/15/busness/economy/coronavirus-worker-risk.html.

Ngussa BM, Makewa LN (2004).Constructivism Experiences in Teaching-earning Transaction among Adventist Secondary Schools in South- Nyanza, Tanzania. American J. Educ. Res. 2(11 A) 1-7

O'Neil E (2020). What is remote learning and how to implement it in your organization? https://www.learnupon.com/blog/what-is-remotelearning/

Paschal MJ, Mkulu DG (2020). Online classes during COVID19 pandemic in higher learning institutions in Africa. Global Research in Higher Education. 3(3):1-21.

Pete J, Soko J (2020). Preparedness for online learning in the contexts of Covid 19 in selected Sub-Saharan African countries. Asian J. Distance Learning 15(2):37-47.

Redacteur D (2018). La rentree scolaie 2018-2019 en chiffre. Etudiant-Algerien. https://etudiantalgerien.com/2018/09/la-rentree-scolaire-2018-2019en-chiffres/.

Reimers, Fernando, M, Schleicher, Andreas (2020). A framework to guide an Education response to the COVID19 pandemic of 2020. OECD. Retrieved 5 July 2020.

Sahu P (2020). Closure of universities due to coronavirus disease, 2019 COVID-19 Impact on education and mental health of students and academic staff. Cures 12(4) 1-6 DOI: $10.7759 /$ cures.7541

Selvan GS (2020). COVID-19 tests self- learning skills of students today. Daily Nation. https://www.nation.co.ke/oped/option/Covid-19-testsself-learning-skills-of-students-today/440808-5534756134a8bhz/index.html.

Sintema EJ (2020). Effect of COVID-19 on the Performance of Grade 12 Students: Implications for STEM Education. EURASIA Journal of Mathematics Science and Technology Education 16(7):1-6.
Sun L, Tang Y, Zuo W (2020). Coronavirus pushes education online. Southeast University, Nanjing, China. Available at https://doi.org/10.1038/s41563-020-06788.

Tagoe M (2012). Students' perceptions on incorporating elearning into teaching and learning at the University of Ghana. International Journal of Education and development Information and communication and Technology, 8(1):1-91.

TAMISEMI, (2020). Taarifa kwa umma kuhusu mpango wa ufundishaji kwa njia ya mitandao television.https://www.tamisemi.go.tz/storage/app/me dia/uploadedfiles/elimu\%20njia\%20ya\%20mtandao\%20\%taarifa\%kwa\%20umma.pdf

TBC (2020). Breaking News: Shule na vyuo vyafungwa kwa muda usiojulikana. https://www.youtube.com/watch?v=QUrVkhCGOXI

UCU. (2020). Statement of Easter semester Examinations Uganda Christian University .

UNDP (2020). Coronavirus disease COVID-19 Pandemic. Retrieved July 2020 from https://www.undp.org/content/undp/en/home/corona virus.html

UNESCO (2020a). Distance learning solutions. https://en.unesco.org/covid19/educationresponse/solut ions

UNESCO, (2010). World conference on high education 2009 final report. Paris: United Nations Educational, Scientific and Cultural Organization

UNESCO. (2020b). COVID-19 Educational Disruption and Responses. Retrieved in 2020-04-12

UNICEF (2020). UNICEF and Microsoft launch global learning platform to help address COVID-19 education crisis. https://www.unicef.org/press-releases/unicefand-microsoft-launc-global-learning-platform-helpadress-covid-19-education

Vygotsky LS (1978. Mind and Society. The Development of Higher mental process. Cambridge: Harvard University Press.

WHO (2020a). Coronavirus diseases COVID-19 Pandemic. World Health Organizations. https://www.who.int/emergencies/diseases/novelcoronavirus-2019

WHO (2020b). Key Messages and Actions for COVID-19 Prevention and Control in Schools. Retrieved from https://www.who.int/docs/default-

source/coronaviruse/key-messages-and-actions-forcovid-19-prevention-and-control-in-schools-march2020.pdf?sfvrsn=baf81d52_4

WHO (2020c). Modes of transmission of virus causing COVID-19: implications for IPC precaution recommendations. Retrieved 5 July 2020, from https://www.who.int/newsroom/commentaries/detail/modes-of-transmission-ofvirus-causing-covid-19-implications-for-ipc-precautionrecommendations

WHO. (2020). Report of the WHO- China Joint Mission on 
coronavirus Disease 2019. Retrieved from https://www.who.int/docs/defaultsource/coronavirus/who-china-joint-mission-oncovid19-final-report.pdf. (Accessed March 2020). 